\title{
IMÁGENES PARA UN POEMA AUTOBIOGRÁFICO. DOCUMENTALIDAD Y LIRISMO FÍLMICO EN PERSONA, DE INGMAR BERGMAN
}

\author{
IMAGES FOR AN AUTOBIOGRAPHIC POEM. DOCUMENTALITY AND FILMIC \\ LYRICISM IN PERSONA, BY INGMAR BERGMAN
}

\author{
David VÁZQUEZ COUTO \\ Universidad de Salamanca \\ davidcouto@usal.es
}

Resumen: En Persona (1966), Ingmar Bergman reflexiona sobre la naturaleza de la imagen enfatizando su aspecto enigmático. Las reproducciones técnicas de las imágenes actúan simultáneamente como ventanas y barreras del mundo, como el mundo en sí mismo, desde su condición de objeto documental que forma parte de la memoria individual y colectiva del hombre. En el ojo del huracán se encuentran la realidad y su representación, y más concretamente, una realidad subjetivada expresada en un cine poético que explora la imagen como signo extralingüístico. Bergman realiza así una obra con existencia propia, autoconsciente y autorreferencial, que reproduce los sueños de su consciencia a través de la pantalla cinematográfica.

Palabras clave: Ingmar Bergman. Persona. Cine. Imagen.

Abstract: In Persona (1966), Ingmar Bergman reflects on thenature of the image emphasizing its enigmatic look. Thetechnical reproductions of images simultaneous lyactas windows and barriers of the world, as the world itself, from its status as documentary object that is part of the individual and collective memory of man. In the eye of the hurricane they are reality and its representation, and more specifically, a reality subjectified expressed in a poetic film that explores the image as extra linguistic sign. In this way Bergman makes a work with its own existence, self-conscious and self-referential, which reproduces the dreams of his consciousness through the cinematographic screen.

Key Words: Ingmar Bergman. Persona. Cinema. Image. 


\section{EL SUEÑO DEL CINE LÍRICO}

En los albores del cine, entre 1902 y 1903, Edwin S. Porter realiza Life of an American Fireman y The Great Train Robbery para la Edison Manufacturing Company, inaugurando así un modelo de narración fílmica que en 1915se institucionaliza con The Birth of a Nation, de D.W. Griffith. A partir de este momento, el lenguaje cinematográfico evoluciona sobre las pautas narrativas del relato literario decimonónico en busca de una aproximación naturalista de la representación. La contrapartida a este sistema que limita la figura del autor tras una estructura convencional se encuentra en un tipo de cine que descubre su autonomía artística al desprenderse de toda herencia estética procedente de otras manifestaciones artísticas como el teatro, la pintura, y, por supuesto, la novela.

En 1965 Pier Paolo Pasolini aboga, desde una perspectiva semiótica, por este cine poético que anhela emanciparse del relato prosaico desde un "estilo indirecto libre" (1970: 25). Y es que el cine, según Pasolini, debe ser articulado con un lenguaje propio cuyo código natural no existe, puesto que el carácter concreto de la imagen, del im-signo', como él lo llama, implica un vacío conceptual que la convierte en elemento irracional configurador del cine como medio de representación onírico y pulsional. Se trata del mismo supuesto del que ya habían partido algunos vanguardistas como Fernand Léger, René Clair, Man Ray, Germain A. Dulac, o Hans Richter², entre otros, aunque es la realización de Un chien andalou (1929), de Luis Buñuel ${ }^{3}$, lo que supone el gran intento por alcanzar "el ideal de acercar el arte cinematográfico al modelo de la lengua poética con su capacidad de superar (o anular) los nexos lógicos entre los significantes de la lengua para hacer aflorar los significados irracionales u ocultos (Pérez Bowie, 2008: 23). Sin embargo, como apunta Pasolini refiriéndose a esta pieza, a pesar de que el director español alcanza un nivel límite "donde la poeticidad del lenguaje se evidencia exasperadamente" (1970: 21), todavía es un producto dependiente de una estructura de signos relativos al surrealismo. Y no solo eso, si se tienen en cuenta las palabras de Jean Vigo que consideran esta obra como un paradigma de documental de temática social, puesto que el posicionamiento

1 El propio Pasolini se encarga de aclarar este neologismo en la obra Entretiens avec Pier Paolo Pasolini de Jean Duflot: "Llamo a las imágenes cinematográficas im-signos. [...] mientras que todos los restantes lenguajes se expresan a través de sistemas de signos simbólicos, los signos del cine no lo son; son iconográficos (o icónicos), [...] mientras los restantes modos de comunicación expresan la realidad a través de los simbólicos, el cine expresa la realidad a través de la realidad" (Pasolini y Rohmer, 1970: 12).

2 Hans Richter reconoce abandonar a un estado "virginal del sueño" la composición conceptual de su obra experimental Filmstudie (1926) (Mitry, 1989: 155).

3 El director aragonés, Luis Buñuel, afirma que "el mecanismo productor de imágenes cinematográficas, por su manera de funcionar, es, entre todos los medios de expresión humana, el que más se parece al de la mente del hombre, o mejor aún, el que mejor imita el funcionamiento de la mente en estado de sueño. El film es como una simulación involuntaria del sueño" (Buñuel, 1958: 2). 
del autor otorga una perspectiva única sobre lo representado, que, en este caso, se lleva a cabo además como un "drama interior desarrollado en forma de poema" (1980: 128). Vigo alude aquí a una condición paradójica de la obra al descubrir un valor ideal de documentalidad habitando en un universo surrealista, gracias al uso poético y subjetivo de la imagen. Esto advierte de la dificultad inherente en la definición de la representación realista mediante imágenes que operan como arquetipos lingüísticos procedentes de la memoria y del sueño, o sea, como imágenes de "comunicación con nosotros mismos" (1970: 19).

En consecuencia, el camino de la modernidad cinematográfica pasa por una búsqueda de su autonomía artística desde una autoridad creadora que lleve las riendas de su construcción, por lo que Pasolini reivindica que"la tendencia del lenguaje cinematográfico debería de ser una tendencia expresivamente subjetivo-lírica" (1970: 20). En 1966, un año después de que Pasolini redactara por primera vez estas teorías, Ingmar Bergman lleva a la praxis cinematográfica algunas de sus ideas mediante la realización de Persona. La película, compleja y de múltiples rostros (también teóricos), se presenta a sí misma como ficción en una lucha ininteligible con la realidad. La primera imagen del film surge de una oscuridad iluminada con la fuente incandescente de un proyector cinematográfico. Este, al combustionar, desencadena una sucesión de imágenes a un ritmo frenético y errático, sin sujeción argumental ni coordenadas de continuidad entre ellas, sin sentido. Entre las imágenes que aparecen tras la explosión lumínica es posible distinguir fragmentos de dibujos animados, lo que parece ser un film Pathé ${ }^{4}$, el cinematógrafo con sus engranajes, sonidos y material fílmico, la palabra start invertida sobre un fondo blanco, un falo en erección, unas manos de niño, una tarántula, un cordero degollado, su ojo cristalino sin vida, vísceras, un clavo atravesando la palma de una mano, una pared de ladrillos que da paso a un bosque nevado, unas rejas de hierro, más nieve, la boca de una anciana, su rostro, un niño sobre una cama de hospital. En este momento, el espectador intuye que la acción se desarrolla en una morgue, pero el niño se despierta con el ruido de un teléfono que viene del exterior de la sala -en su interior solo se escucha el goteo de un grifo-. El niño se pone unas gafas y comienza a leer Un héroe de nuestro tiempo, de Lermontov, pero algo le llama la atención. Se gira hacia la cámara, nos mira y pasa la mano por delante del objetivo, pero al otro lado está la superficie de una pantalla en la que se suceden los rostros combinados y difusos de las dos protagonistas de la película. El niño toca la imagen, la palpa en busca de sus cualidades mientras el espectador ocupa

$4 \quad$ No se trata de un film Pathé real, sino de una reconstrucción de un trozo de película que Bergman había adquirido en el almacén Claestorspsboden. La nueva versión, interpretada por los Bargazzi, se lleva a cabo para formar parte de Fängelse (Prisión, 1949). Pere Gimferrer (1999: 37) llega a confundir la escena con un film de Mélies en su ensayo Cine y literatura. 
el lugar de la pantalla, y, por consiguiente, de los rostros que se proyectan en ella [Figura 1]. Sobre esta escena, Susan Sontag sugiere que "la superficie que toca induce a pensar en una pantalla cinematográfica, pero también en un retrato y en un espejo" (2007: 169), lo 1], que implica, en cierta medida, una equivalencia conceptual y la identificación personal.

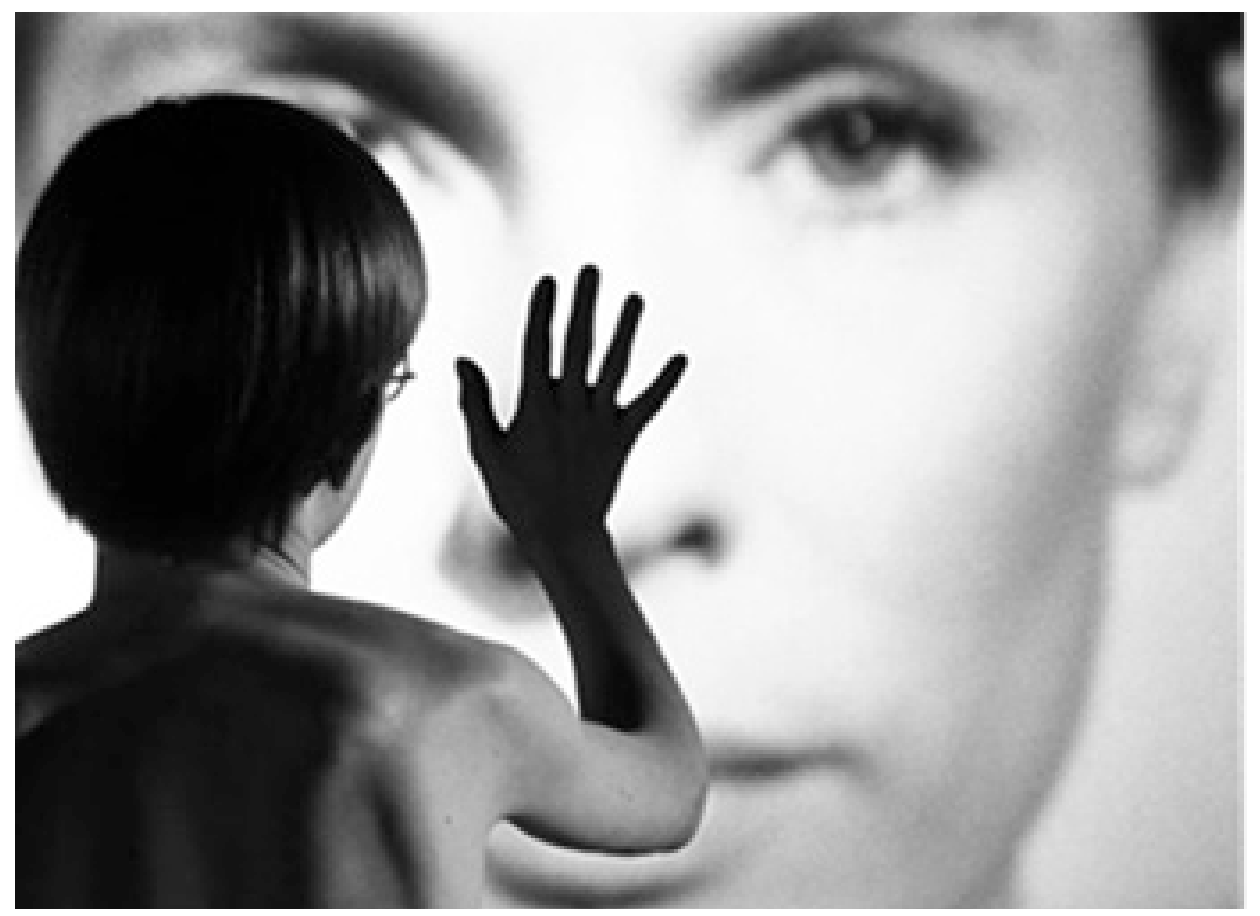

Figura 1. BERGMAN, I. (1966). Persona. min. 5 y 72.

En 1969 Bergman explica cuál fue la concepción primaria de este mosaico simbólico5: “Tenía una idea bastante vaga de hacer un poema, no con palabras sino con imágenes, un poema sobre lo que dio origen a ese film. Desprendí por tanto los elementos esenciales, y comencé a poner en marcha mi pequeño proyector interior" (Björkman, Manns \& Sima, 1973: 200). Estos elementos esenciales se traducen en imágenes iconográficas pertenecientes a la subjetividad del autor que constituyen un todo, un poema y un sueño, mediante un proceso de exaltación del recuerdo. El torrente de imágenes extraídas "del sordo caos de las cosas" (1970: 16), que diría Pasolini, busca emanciparse al pensamiento de forma instintiva como hacen los sueños, porque "cada sueño es una serie de im-signos, que tiene todas las características de las secuencias cinematográficas"(Pasolini, 1970: 12).

5 Término extraído de J. M. Company (1999). 
En repetidas ocasiones, mediante escritos y entrevistas, Bergman reconoce el carácter subjetivo y autobiográfico de la composición poética de Persona: "La película que pasa por el proyector vertiginosamente y estalla en imágenes y breves secuencias era algo que yo había llevado dentro mucho tiempo" (2007: 55). Además de las imágenes que tienen un valor simbólico-religioso para el autor -el cordero de Dios o el Dios araña a los que hace referencia en algunas de sus películas-, también existen referencias a su infancia ligada al momento presente, es decir, a una infancia todavía inconclusa. "Jugué al niño que había muerto" (Björkman, Manns \& Sima, 1973: 200), dice Bergman, pero lo resucita en un depósito de cadáveres en el que él mismo había estado poco antes del rodaje de la película. Los trozos de celuloide pasan por delante de la luz del cinematógrafo como los retales de película de nitrato manipulados por aquel niño. Cortando y juntando los pedazos, disolviendo la emulsión y dibujando sobre el fotograma en blanco, Bergman jugaba a componer nuevas historias con imágenes cuya conexión discursiva se fundamentaba en el vacío entre los fotogramas que son ocupados por la imaginación (Bergman, 2007: 55). Muchos años más tarde, él mismo recuerda en sus memorias cómo las cualidades del cine le devuelven a la experiencia de la niñez:

Cine como sueño, como música. No hay arte que, como el cine, se dirija a través de nuestra conciencia diurna directamente a nuestros sentimientos, hasta lo más profundo de la oscuridad del alma. Un pequeño defecto del nervio óptico, un efecto traumático: veinticuatro fotogramas iluminados por segundo, entre ellos oscuridad, el nervio óptico no registra la oscuridad. Cuando yo, en la moviola, paso la película cuadro por cuadro siento todavía la vertiginosa sensación de magia de mi infancia (1988: 84).

Poco a poco, tras este primer cúmulo caótico de imágenes, la velocidad de sucesión de fotogramas se ajusta a un tempo narrativo que se acerca a la tragedia naturalista, no obstante, el fin de este prólogo poético insertado en la obra marco parece estar en la obra misma. Nace, vive y muere paralelamente a la obra a la cual pertenece, confundiéndose entre sus imágenes en un mise en abyme que impide toda distinción entre fantasía y realidad al incitar al espectador a rebasar los horizontes diegéticos del film. Sontag aprecia que durante el desarrollo de la película "las alucinaciones surgirán de la pantalla con los mismos ritmos y la misma apariencia de realidad objetiva que tienen los elementos reales" (2007: 160). Lo que el espectador ve es lo proyectado por el dispositivo cinematográfico que ya no funciona como elemento externo a la narración, sino como una parte indisociable de ésta que surge de su interior. El cinematógrafo hace acto de presencia en Persona en su inicio y su final, pero también durante su meridiano, 
cuando un fallo en el reproductor fílmico provoca la combustión del fotograma que aniquila el rostro de Alma (Bibi Andersson). Bergman muestra al espectador de la película el mismo aparato fílmico que la proyecta, llevando todavía más lejos la idea sugerida por Pasolini de hacer notar la cámara mediante la manipulación técnica que formaliza el punto de vista subjetivo del autor (1970). Al insertar "la presencia sentida de la película como objeto en la conciencia del espectador" (Sontag, 2007: 172), Persona se desmarca de los estilos directo e indirecto para convertirse en su propia narrativa autoconsciente. Aquí el sujeto es el objeto, y el narrador es la narración misma. Se produce, pues, una "personificación" del film. Bruce Kawin, en su estudio sobre Persona, explica que "...the film's self-consciousness appears to originate from within. Without being identified with a specific character, or with the filmmaker, the potential linguistic focus takes on the characteristics of a mindscreen. The film becomes first-person, it speaks itself" (1978: 113-114). Desde éste último concepto, mindscreen ${ }^{6}$, Kawinafronta el conflicto de la representación del mundo interior del director estableciendo una analogía entre el campo visual fílmico y el onírico. Se trata de la proyección del sueño del autor, de las imágenes surgidas de su imaginación y reflejadas sobre la pantalla de cine bajo una estructura discursiva en primera persona y autoconsciente. El relato antirrelato aborda, por tanto, la compleja confrontación entre ilusión y realidad desde un subjetivismo lírico llevado al extremo, donde la reflexión ontológica de la imagen se realiza desde la imagen misma.

\section{HACIA EL INTERIOR DE LA IMAGEN (DE LA MANO DE ROLAND BARTHES)}

Cuando Luis Buñuel habla sobre la famosa escena del ojo cortado con una navaja de afeitar en Un chien andalou, demuestra una inclinación conceptual de la imagen que le otorga el deber de impacto y conmoción sobre el receptor con el fin de anular su capacidad de establecer conexiones referenciales con ésta, es decir, de imposibilitar una interpretación que otorgue connotación a la imagen: "Para sumergir al espectador en un estado que permitiese la libre asociación de ideas era necesario producirle un choque casi traumático en el mismo comienzo del filme" (Sánchez Vidal, 1991: 133). De la misma manera, Bergman, ya en el nudo de la película, empuja a su protagonista y a los espectadores a contemplar imágenes documentales cuyas cualidades provocan una conmoción durante su recepción. Robin Wood mantiene que "[Bergman] draws the spectator into the film demanding total emotional involvement" (1969: 145), y, en

6 Bruce Kawin toma la idea de mindscreen del concepto dreamscreen acuñado por el psicólogo norteamericano Bertram D. Lewinen (1950). 
consecuencia, posiciona al espectador tras la mirada del personaje principal, Elisabet Vogler (Liv Ullmann), para observar el mundo a través de sus ojos y experimentar una percepción análoga. Acercándose al concepto de "imagen-tiempo", propuesto por Deleuze, como elemento asociado al nacimiento del cine moderno, Bergman prioriza"una situación óptica y sonora pura" sobre la temática argumental, no obstante, precisamente esta situación en la que "el personaje se ha transformado en una especie de espectador del film" (Deleuze, 1987: 13) se convierte en la muestra de la idea subyacente en el metraje. El espectador de Persona asiste, por dos veces, a la contemplación del horror en la pantalla, además de tener la posibilidad de ver su propio reflejo en el rostro de Elisabet.

Una de estas situaciones se produce cuando Elisabet se encuentra con una fotografía entre las hojas de un libro. La escena fotográfica parece ser la de una evacuación forzosa de las familias judías refugiadas en un edificio clandestino por parte de los soldados alemanes durante la Segunda Guerra Mundial'7. Bergman fragmenta la imagen y la concentra en sus detalles, analiza las expresiones congeladas en los rostros de sus protagonistas hasta detenerse en la figura de un niño con gesto temeroso y las manos en alto (¿quizá las manos que aparecen fugazmente en el prólogo poético son una reminiscencia onírica de esta imagen?).

7 Fotografía tomada por Jürgen Stroop como parte de un reportaje para Heinrich Himmler durante el levantamiento del gueto de Varsovia en mayo de 1943. 

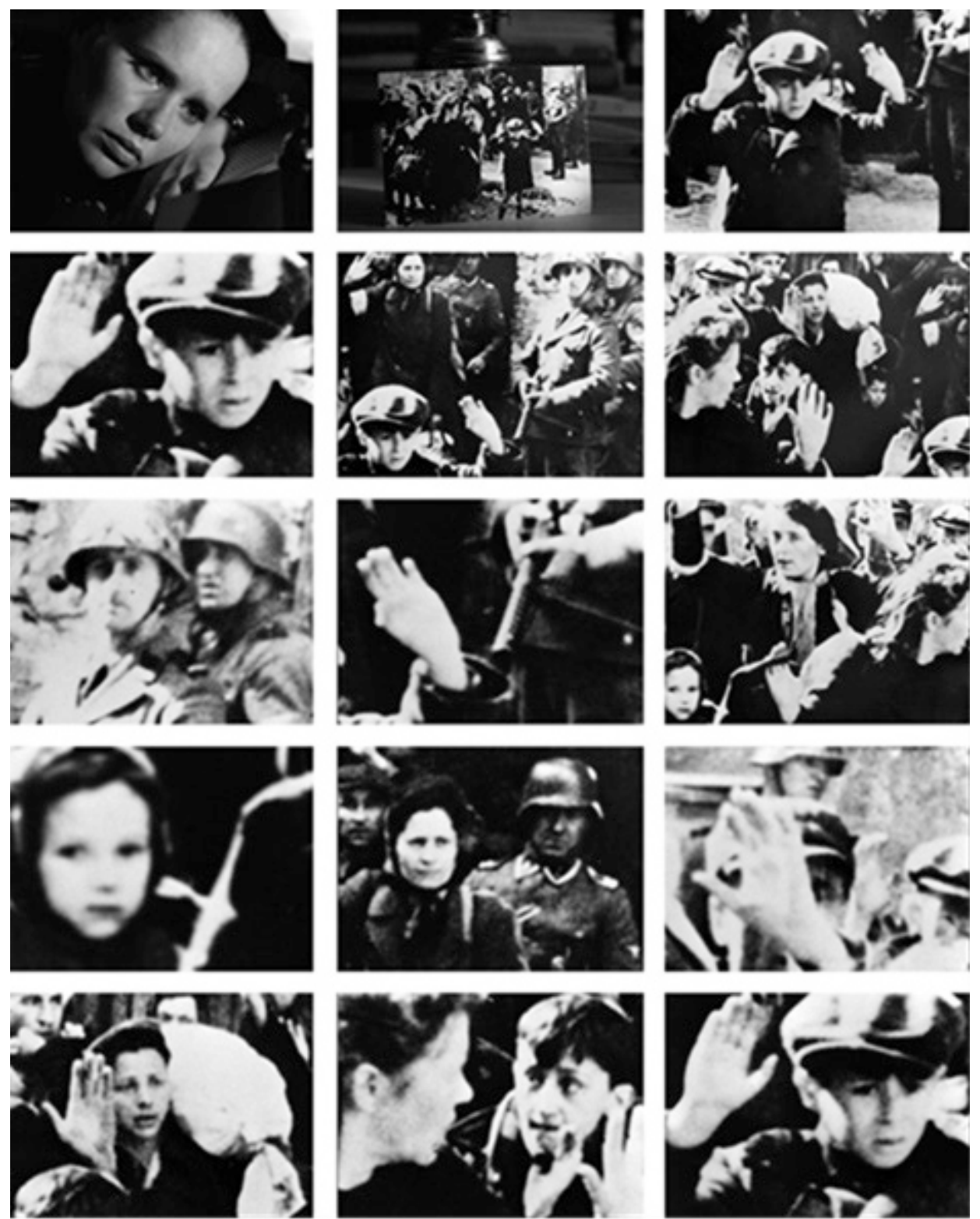

Figura 2. Fotogramas de la secuencia completa. I. Bergman (1966). Persona. min. 59. 
Elisabet, inmersa en la contemplación, reflexiona y recuerda, imagina lo que ha sucedido, lo que ha sido de aquellas personas. Es entonces cuando la imagen atrapa y estremece durante un momento de calma, es subversiva en el sentido utilizado por Roland Barthes ${ }^{8,}$ incitando así a una respuesta activa en el receptor que deriva en una conmoción procedente del sentido obtuso de la imagen, o de lo que más tarde el autor francés llamará punctum ${ }^{9}$. Debido a que ambos conceptos mantienen una distancia fundamentalmente terminológica (Del Río, 2008: 41), operan bajo la misma condición de atributo de la imagen que engloba la cualidad huidiza a su entendimiento. En base al análisis de algunos fotogramas de Ivan Groznyy (Iván el Terrible, 1944), de Sergei M. Eisenstein, Barthes postula el tercer sentido o sentido obtuso ${ }^{10}$ como un "significante sin significado" (1986: 42) que aparece a espaldas del sentido obvio, oculto tras lo aparente, indescriptible, ininteligible e inabarcable a nivel semiótico. El espectador es, por tanto, presa de aquello que retiene la fotografía, de sus gestos y expresiones, de multitud de detalles prácticamente imperceptibles que provocan un efecto desconcertador durante su contemplación.


Figura 3. I. Bergman. (1966), Persona. min. 15-16.

En otra ocasión, guarecida del mundo en un hospital psiquiátrico, Elisabet se enfrenta a través de la pantalla del televisor al napalm que arde sobre el cuerpo de un monje budista que se quemó a lo bonzo en las calles de Saigón en 1963 [Figura 3]. El dato histórico, que obtiene su utilidad en su identificación como documento, es precisamente el que debe omitirse para su interpretación, puesto que Bergman arranca la imagen de las manos del poder ideológico para llevarlas a un terreno que trasciende a todo

8 "En el fondo, la fotografía es subversiva, y no cuando asusta, trastorna o incluso estigmatiza, sino cuando es pensativa" (Barthes, 1989: 81).

9 "En el punctum de una foto es ese azar que en ella me despunta pero que también me lastima, me punza" (Barthes, 1989: 59).

10 Aunque el origen conceptual de ambos términos se remonta a un capítulo de sus Mitologías (1954-56) dedicado a una exposición en la galería d’Orsay que recopilaba fotos-impactos, la idea del tercer sentido o sentido obtuso aparece desarrollada por primera vez en R. Barthes (1970), "Le troisième sens. Notes de recherche sur quelques photogrammes de S. M. Eisenstein". 
referente: el sufrimiento y el dolor contenido en la crudeza de la escena. Así lo plantea Nöel Burch cuando afirma que esta "ya no es una imagen con significación política, sino una imagen de la violencia e injusticia de los hombres, y por tanto un componente poético necesario en este momento del film" (1985: 141). Por su parte, el director sueco reflexiona sobre el carácter íntimo de la percepción del horror: "Jamás logro librarme de esas imágenes" (2007: 56), admite sin reservas en sus diarios de rodaje. Y es que este efecto en la memoria tiene su origen en el trauma «que deja en suspenso el lenguaje y bloquea la significación", puesto que "cuanto más directo es el trauma, más difícil resulta la connotación" (1986: 26).

En consecuencia, los signos que forman la imagen traumática pierden su sentido debido a que el impacto ejercido sobre el receptor inhabilita sus capacidades de aplicar un código ideológico a la escena. El espectador se acerca así al componente misterioso de lo real mediante una denotación pura de la imagen. Bergman explica esta sensación al encontrarse por primera vez con las imágenes que salieron a la luz tras el final de la Segunda Guerra Mundial: "Cuando los testimonios de los campos de concentración se abatieron sobre mí, mi entendimiento no fue capaz, en un primer momento, de aceptar lo que veían mis ojos" (2007: 135-136). Se deduce de estas palabras que Bergman sufre el colapso que anula su dialéctica con el mundo en un momento de interrupción de lo familiar, liberando así a la imagen de su connotación cultural y dejándola a solas con el "mensaje sin código" de su análogo fotográfico (Barthes, 1986: 13). Esta inconcreción es para Barthes el "acto fundador de lo fílmico" (1986: 65), aquello que dota al film de una profundidad inalcanzable, pues se encuentra en el agotamiento de lo cognoscible, en ese punto de inflexión que limita el conocimiento analítico de la imagen: "Lo fílmico es lo que no puede describirse, la representación que no puede ser representada. Lo fílmico empieza donde acaban el lenguaje y el metalenguaje articulado" (1986: 64). Sin embargo, Barthes advierte sobre la particular condición que hace posible lo fílmico, y es que este fenómeno solo puede aparecer en el instante detenido del fotograma que "nos entrega el interior del fragmento" (1986: 65-66). Cada vez a mayor profundidad, Barthes se sumerge en el océano de la imagen llevándola hasta el límite del sentido, hacia un sentido obtuso que guarda relación con el contenido íntimo del fotograma. Lo fílmico, en cuanto a fenómeno estrechamente vinculado al sentido obtuso, parece descubrir la esencia del fragmento de aquel mundo de Empédocles -más tarde retomado luego por Deleuze-, pero en su derivación técnica que opera como simulacro de lo real.

Ahora bien, Bergman persigue la idea de aislar la unidad indivisible del objeto cinematográfico de la misma manera que Barthes aísla el fotograma para limitar el fenómeno de lo fílmico. Y, si "el fotograma se libera de la constricción del tiempo filmico" (Barthes, 1986: 67), Persona, en su totalidad, propone algo semejante mediante su construcción narrativa. Al igual que en un sueño, la distensión temporal y espacial 
altera el discurso de tal manera que "un segundo debe poder extenderse durante un largo periodo de tiempo y contener un puñado de réplicas esparcidas sin coherencia" (Bergman, 2007: 54). Aquí no tiene cabida el tiempo lógico por el que transcurre el cine clásico o de prosa que disocia lo fílmico de las exigencias técnicas, por lo que es posible mantener la hipótesis de que la intención del film es sustraer al espectador como lo haría el instante paralizado del fotograma, tal y como ya había sugerido Jean-Luc Godard en 1958, en una retrospectiva dedicada al director sueco en la revista francesa de crítica cinematográfica Cahiers du cinéma:

Un film d'Ingmar Bergman, c'est, si l'on veut, un vingt-quatrième de seconde qui se métamorphose et s'étire pendant une heure et demie. C'est le monde, entre deux battements de paupières, la tristesse entre deux battements de cour, la joie de vivre entre deux battements de mains (1958: 2).

El mismo Barthes admite que "el sentido obtuso es el antirrelato por excelencia", ya que fundamentar la segmentación de la obra bajo su concepción implicaría una "segmentación inaudita, antilógica y, no obstante, verdadera" (1986: 63). Asimismo, el cineasta admite la pretensión de realizar una película "limpia de signos y de imágenes fotográficas" (2010: 17), lo que refleja su postura respecto a una imagen fílmica que se fundamenta en el principio genético del movimiento, como ya había preconizado Germaine A. Dulac en 1927 con su Cinegrafía integral'" . Ahora bien, reconociendo que la esencia del cine es el movimiento, lo fílmico solo existe oculto tras ese movimiento. Es imperceptible por el ojo humano pero está ahí, se siente su presencia espectral entre la continua sucesión de fotogramas. Bergman se esfuerza en capturar aquello que nunca se detiene mediante la distensión temporal, introduciendo al espectador en el material lumínico en movimiento que es el fragmento fílmico, y no la fotografía fija, porque solo a través del movimiento es posible la reconstrucción onírica de un gran fotograma.

\section{PERSONA: DOCUMENTAL DE LA IMAGEN}

La estructura entrópica que rige el mundo originario de las imágenes se traslada a un espacio material fílmico, concreto y objetualizado, donde Bergman pone en práctica la teoría del cine lírico que busca la especificidad de la imagen concibiéndola como un signo extralingüístico. Adaptada al lenguaje onírico de los recuerdos que asaltan al pensamiento como relámpagos, la obertura lírica de Personase esfuerza en eximir a la imagen de un valor connotativo mediante su articulación irracional en el texto filmico.

11 "Concepción del cine puro, del cine desprendido de cualquier aportación extraña, del cine como arte del movimiento y de los ritmos visuales de la vida y de la imaginación" (Dulac, 1980: 94). 
Tomando algunas expresiones del director, Birgitta Steene afirma que "[Bergman] wants to explore what he alternately calls'the dangerous roads' and 'the dramaturgy of the juicy dream.' His goal is to transcend the world of outer action and penetrate into 'the twilight land of suprareality'" (2000: 28). Las intenciones del autor se dirigen entonces hacia la provocación de una desconexión del relato mediante un efecto de impacto sobre el receptor que impide toda corrupción connotativa de la imagen, quedando aislado el análogo técnico de lo real en un instante límite en el que el observador establece una conexión directa e intensa con la imagen, y esta, a su vez, aprovecha la ocasión para enraizar en el fértil terreno de la memoria. Cuando Bergman dice: "I still try the riskier alternative and it turns out that the public also absorbs an advanced irrational line of development with a surprisingly open ear" (Steene, 2000: 29), admite la presunción de una percepción profundamente sensorial de las imágenes por parte del espectador, que debe ser capaz de entablar una conexión sensible con su índice real obedeciendo al instinto pulsional. El cineasta lleva al espectador hacia una "captación poética" de la imagen (Barthes, 1986:50), dotando a la película de un sentido que extiende el fotograma durante setenta y cinco minutos con el anhelo por conocer "esos secretos sin palabras que solo la cinematografía es capaz de sacar a la luz" (Bergman, 2007: 59).

El carácter mitológico de la película, al igual que el de las imágenes del gueto de Varsovia y del monje inmolado, viene dado, en cierta manera, por el efecto traumático que aparece a partir del extrañamiento de la imagen. Para ello, Bergman desprende a la imagen documental del relato histórico, la escinde de un tejido cultural manipulando su estatuto (estatus) con un mecanismo descontextualizador. Sin embargo, aunque la imagen se traslada del espacio documental al artístico bajo una apropiación del autor, existen todavía resquicios conscientes de un anclaje de la imagen al mundo. En su ensayo Fotografía objeto Víctor del Río ahonda lucidamente sobre esta cuestión predominante en el arte neovanguardia de los años 60 y 70 que introduce el documento en el eje de su discurso teórico y práctico:

Las fotografías de archivo, separadas de su contexto original, pierden la capacidad de ser entendidas de forma instrumental, dejan en definitiva de ser documentos, para relacionarse con el imaginario del arte. Tal estética paralela al mundo administrado del que proceden retiene, sin embargo, la conciencia de esa desconexión, la sospecha sobre su origen real y, por tanto, la pregunta irresoluble sobre una procedencia concreta (2008: 24).

A partir de este interrogante que funciona como nexo de una separación, por así decirlo, donde la presunción de un referente primario para la imagen no deja lugar a su total emancipación respecto al ámbito documental, también es posible formular la 
ecuación en un sentido inverso, a saber: que la imagen artística o ficcional adquiere un valor documental al abandonar su marco natural e integrarse en el discurso onírico de la memoria. De esta manera, las imágenes, sea cual sea su procedencia, forman parte de una especie de archivo histórico de la conciencia del espectador que reúne como piezas de anticuario los retazos de filmes antiguos. Bergman lleva hasta sus últimas consecuencias el propósito de evidenciar la naturaleza del cine, que. según Sontag consiste en "conferir a todos los acontecimientos, cuando no existe indicación de lo contrario, el mismo grado de realidad: todo lo que muestra la pantalla está allí, presente" (2007: 159). Y es que al apropiarse de imágenes documentales para introducirlas en la diégesis fílmica, Bergman procura un efecto de realidad homogénea contaminada por la ficción, donde la fluctuación circular de imágenes que constituye Persona, como un juego de reflejos especulares, lleva a la conclusión de una indisolubilidad en las fuentes materiales creadoras de la memoria. Es la idea de una vida convertida en archivo de imágenes, todas documentales y ficcionales, donde "la verdad se ha diluido y desaparecido o en el peor de los casos se ha convertido en una falsedad" (Bergman, 2007: 56).

El cine posee, por tanto, un doble rostro, como aquel que conforma la imagen a la que se enfrenta el niño de la película, ya que por un lado, muestra su condición invariablemente realista, pues lo que la cámara filma queda atrapado por siempre en el material, pasando a ser inmediatamente un documento. Y, por otro lado, revela su carácter surrealista al representar el mundo desde un estilo lírico, que "tiene más que ver con el mundo mental que con lo visible, más con la realidad interna que con la externa" (Gimferrer, 1999: 149).La síntesis conceptual del cine obtiene su forma material en Persona, que, bajo una consciencia autónoma y poética, convierte la subjetividad en un objeto autocontemplativo que reflexiona sobre su condición artística como lo hace el individuo que sueña atrapado en sí mismo. Sontag apunta hacia una intención del autor de enfatizar y llevar a profunda reflexión la paradoja inherente al cine: aquella "que siempre produce la ilusión de acceso indiscreto a una realidad que no ha sido manipulada, de visión neutral de las cosas tal como son: Lo que se filma es siempre, en cierto sentido, un documento" (2007: 171).

Persona se convierte, por tanto, en un documento en forma de poema autobiográfico construido con imágenes en movimiento, un sueño materializado sobre la pantalla de cine que se cuestiona su propia existencia y representación. De esta manera, mientras Ingmar Bergman se sitúa en la vanguardia de la modernidad artística al plantear una objeción al estatuto de la imagen que configura el lenguaje cinematográfico, el cine entra en una nueva etapa que interroga sobre la condición de la imagen como génesis irracional del pensamiento. 


\section{REFERENCIAS BIBLIOGRÁFICAS}

BARTHES, R. (1986). Lo obvio y lo obtuso. Imágenes, gestos, voces. Barcelona: Paidós. (1989). La cámara lúcida. Barcelona: Paidós

(1970). "Le troisième sens. Notes de recherche sur quelques photogrammes de S. M.

Eisenstein". Cahiers du cinéma 222, 12-19.

BERGMAN, I. (1988). Linterna mágica. Barcelona: Tusquets.

(2007). Imágenes. Barcelona:Tusquets.

(2010). Persona. Madrid: Nórdica Libros.

BJÖRKMAN, S; MANNS, T. y SIMA, J. (1973). Conversaciones con Ingmar Bergman. Barcelona: Anagrama.

BUÑUEL, L. (1958). “El cine, instrumento de poesía”. Revista Universidad de México XIII.4, 1-15.

COMPANY. J. M. (1999). Ingmar Bergman. Madrid: Cátedra.

DELEUZE, G. (1987). La imagen-tiempo. Estudios sobre cine 2. Barcelona: Paidós Ibérica.

DEL RíO, V. (2008). Fotografía objeto. La superación de la estética del documento. Salamanca:

Ediciones Universidad de Salamanca.

DULAC, G. A. (1980). "Las estéticas. Las trabas. La Cinegrafía integral”. En Fuentes y documentos del cine, J. Romaguera i Ramió y H. Alsina Thevenet (eds.), 87-95. Barcelona: Gustavo Gili.

[Texto originalmente publicado en el tomo II de L'Art Cinématographique (Paris: Libraire Félix Alcan, 1927).]

GIMFERRER, P. (1999). Cine y literatura. Barcelona: Seix Barral.

GODARD, J. L. (1958). “Bergmanorama”. Cahiers du cinéma 85, 1-5.

KAWIN, B. F. (1978). Mindscreen: Bergman, Godard, and First-Person Film. Princeton: Princeton University Press.

MITRY, J. (1989). Historia del cine experimental. Madrid: Siglo XXI.

PÉREZ BOWIE, J. A. (2008). Leer el cine. La teoría literaria en la teoría cinematográfica. Salamanca:

Ediciones Universidad de Salamanca.

PASOLINI, P. P. y ROHMER, E. (1970). Cine de poesía contra cine de prosa. Barcelona: Anagrama. SÁNCHEZ VIDAL, A. (1991). Luis Buñuel. Madrid: Cátedra.

SONTAG, S. (2007). Estilos radicales. Barcelona: Debolsillo.

STEENE, B. (2000). "Bergman's Persona through a Native Mindscape". En Ingmar Bergman's

Persona. Lloyd Michaels (ed.), 24-44. Cambridge: Cambridge University Press.

VIGO, J. (1980). “El punto de vista documental". En Fuentes y documentos del cine, J. Romaguera

i Ramió y H. Alsina Thevenet (eds.), 127-131. Barcelona: Gustavo Gili.

WOOD, R. (1969). Ingmar Bergman. London: Studiovista. 